\title{
Periodical Changes in Soil and Leaf Micronutrients and their Relation to Yield from Alphonso Mango Orchards of Ratnagiri and Devgad, Maharashtra, India
}

\author{
U.Y. Puranik*, Manoj Kumar Dev, S.D. Zodge and S.S. Prabhudesai \\ Department of Soil Science and Agricultural Chemistry, Dr. Balasaheb Sawant Konkan Krishi \\ Vidyapeeth, Dapoli-415712, Ratnagiri (M.S.), India \\ *Corresponding author
}

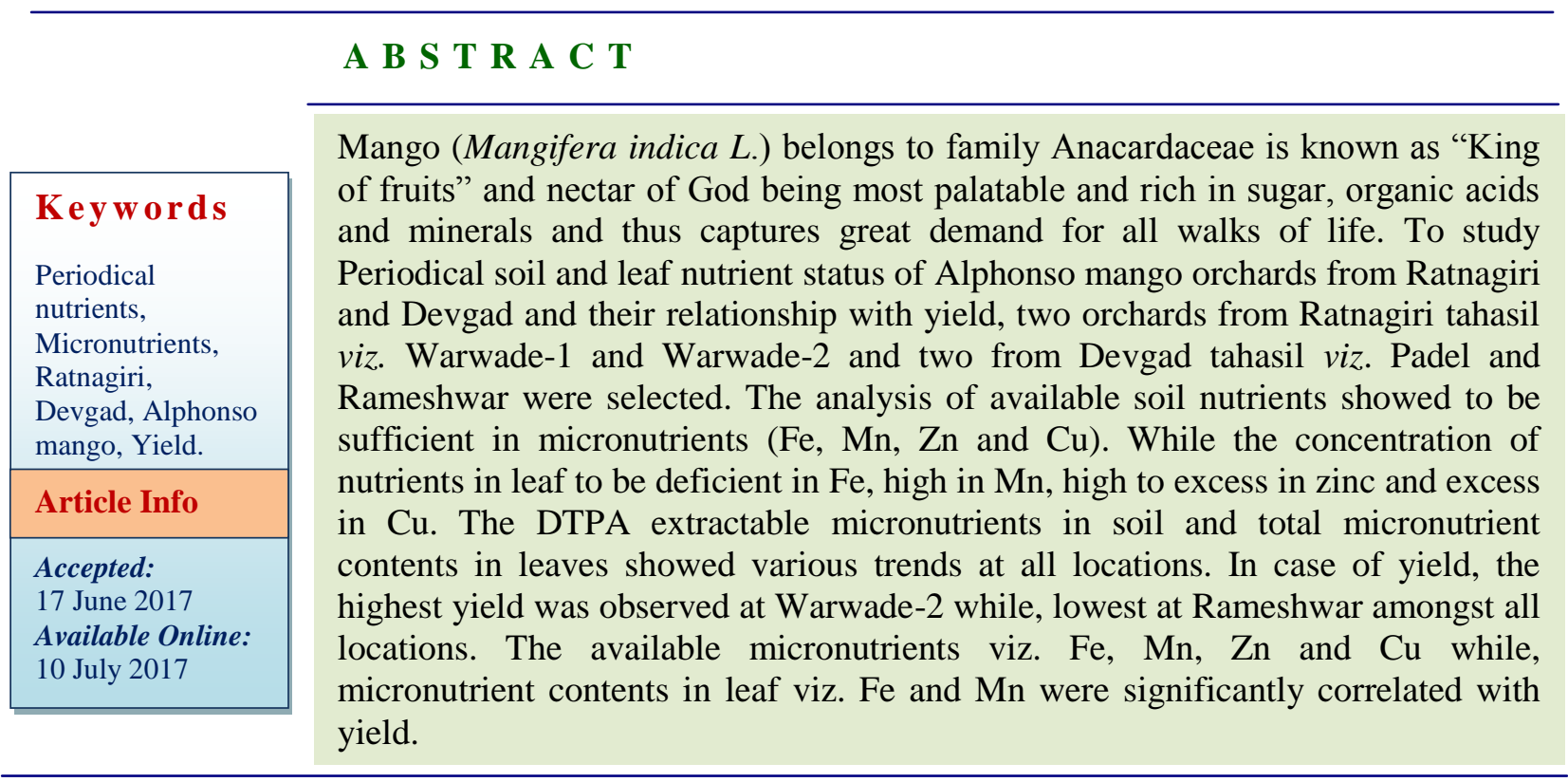

\section{Introduction}

Mango (Mangifera indica L.) belongs to family Anacardiaceae and originating in South East Asia. It is important fruit crop of India grown in area of 4.95 million ha producing 37.12 million tons showing a productivity of 7.51 tons/ha (Anonymous, 2015). Besides taste and good qualities, it is called "The King of Fruits". The Konkan region of Maharashtra is famous and well known for mango production. Particularly, the two districts of the region viz. Ratnagiri and Sindhudurg are known as 'Mango baskets'.
However, the production efficiency of mango orchards can be partially attributed to variations in soil and leaf nutrients (Ray and Mukherjee, 1982). In addition to this, under nutrition and negligence of orchards due to improper management practices are thus been the important reasons affecting the yield in the region (Reddy et al., 2003).

Micronutrients play a vital role in various enzymatic activities and synthesis of assimilates and hormones. As such, much 
work has been done in soils of mango orchards in the Konkan region but very little work has been done in respect of stages. Hence, in light of the available information, sparse related research and to overcome the nutritional problems, the present investigation was undertaken.

\section{Materials and Methods}

Survey of four mango orchards comprising of Alphonso mango variety was done in present study. Two orchards from Ratnagiri tahasil especially at Warwade- 1 and Warwade- 2 and two from Devgad tahasil viz. Rameshwar and Padel were selected. Fifteen trees from each orchard were included in the study.

From each mango orchard, the surface soil samples $(0-15 \mathrm{~cm})$ were collected from fertilizer ring periphery of each tree while, leaf samples of three to four months old and situated at fourth and fifth position from terminal bud were collected at pre-flowering, flowering, egg stage and at harvest stage by following standard method of collection of soil and leaf samples (Tandon, 1993).

The micronutrients in soil were obtained by DTPA method (Lindsay and Norvell, 1978) while, micronutrients in leaf were estimated by using atomic absorption spectrophotometer (Mclaren and Crawford, 1950).

\section{Results and Discussion}

The results obtained are presented in appropriate tables and discussed under suitable headings with abbreviations as follows. The values given in table 2 and 3 are the mean of 15 samples.

\section{Abbreviations}

$\mathrm{W}-1=$ Warwade-1; W-2; Warwade-2; $\mathrm{R}=$ Rameshwar; $\mathrm{P}=$ Padel; $\mathrm{PF}=$ Pre-flowering;
$\mathrm{FF}=$ Full Flowering; $\mathrm{E}=\mathrm{Egg}$ stage; $\mathrm{AH}=\mathrm{At}$ Harvest

\section{Soil micronutrients}

\section{Available iron (Fe)}

The data prescribed in table 2 observed no any definite trend at all locations from preflowering up to harvest. Considering the threshold values for available Fe given by Lindsay and Norvell (1978) all the soil samples had sufficient available iron content. Similar ranges of available $\mathrm{Fe}$ was also reported by Patil and Meisheri (2004).The increase in the content may be due to addition of manures and which may be responsible for creating more availability of nutrient. However, its decrease might be attributed to its absorption from soil by tree for flowering and fruit development (Yawalkar et al., 2011). Organic amendment especially FYM increases the concentration of many nutrients. Organic acids such as citric, malic, oxalic and phenolic that form Fe complexes are released when organic matter decomposes. These Fe complexes enhance the mobility and bioavailability of $\mathrm{Fe}$ (Lindsay, 1991). The high content of available Fe was found in the surface soils and it may be due to accumulation of sesquioxides and also high organic matter content which keeps iron in complexes and available form (Katyal et al., 1982). Diwan, (1982) also explained that the sufficient amount of available $\mathrm{Fe}$ in lateritic soil may be due to laterization processes in which sesquioxides accumulate to increase the Fe content and also it may be attributed to low $\mathrm{pH}$ and higher organic matter content of soil.

\section{Available manganese (Mn)}

The available manganese gradually decreased from pre-flowering to flowering stage. At egg stage, it found to be increased and again 
decreased at harvest of fruits at all locations except Warwade-2. At Warwade-2, the available Mn content in soil increased up to flowering stage and further decreased at harvest (Table 2). The increase in manganese content may be due to addition of organic manures and enhancement of microbial activity and its decrease might be attributed to its use by tree for flowering and production (Pathmanabhan et al., 2008). In general, all the mango orchards showed adequate amount of available $\mathrm{Mn}$ content on the basis of critical limits given by Lindsay and Norvell (1978). The high concentration of available Mn may be due to decomposition and mineralization of organic matter due to warm and humid climate of the region (Mehta and Patil, 1967) and might be due to chelating action of organic compounds released during the decomposition of manures (Chinchmalatpure et al., 2000).

\section{Available zinc (Zn)}

In case of available zinc, the decreasing trend was observed from pre-flowering stage up to egg stage. At harvest of the fruits, the available zinc got decreased at all locations except Warwade-1. At warwade-1, decreasing trend was observed from pre-flowering stage up to harvest. As per the critical limits given by Lindsay and Norvell (1978) all the soil samples were sufficiently supplied with available $\mathrm{Zn}$ at all locations. In this context, Patil et al., (2010) and Pawar (2012) observed the similar ranges of available zinc in mango orchards. In general, adequate level of available $\mathrm{Zn}$ in lateritic soils might be associated with presence of large amounts of organic matter and hydrous oxides of $\mathrm{Fe}, \mathrm{Al}$ or Mn (Tandon, 1993). The decrease in content may be due to its consumption through absorption by tree for its vegetative and reproductive growth (Emanuel and bloom, 2004). In this connection Tisdale et al., (1993) explained that the increasing soil temperature increases the availability of zinc to crops by increasing solubility and diffusion of $\mathrm{Zn}^{++}$. The availability of zinc might be decreased due to decrease in temperature during flowering and egg stage of fruit.

\section{Available copper ( $\mathrm{Cu})$}

As per the data given in table 2, decreasing trend was noticed at all locations except Rameshwar from pre-flowering stage up to harvest in case of available copper. At Rameshwar, decreasing trend was noticed from flowering stage up to harvest. According to the critical limit suggested by Lindsay and Norvell (1978), the available $\mathrm{Cu}$ content of soil showed sufficient range at all growth stages. The study of Mehta and Patil, (1967) also revealed that due to decomposition and mineralization of organic matter because of warm and humid climate of the Konkan region the concentration of available copper content in soil is higher. The similar values of available copper were also noticed by Salvi (1988). The decrease from flowering stage to harvesting stage at Padel location may be due to its consumption through absorption by tree for its vegetative and reproductive growth. At soil organic matter levels up to $8 \%$, both organic and mineral surfaces are involved in $\mathrm{Cu}$ adsorption, while at higher concentration of organic matter, binding of copper takes place mostly on organic surfaces. For soils having similar clay and organic matter content, the contribution of organic matter to the complexing of $\mathrm{Cu}$ will be highest when the predominant clay mineral is kaolinite and lowest with montmorillonite (Tisdale et al., 1993).

\section{Leaf nutrients}

\section{Total iron (Fe)}

At Warwade-1 and Rameshwar, the total iron content in leaf seen to have increased from pre-flowering to egg stage and found to have decreased at harvest. While, at Warwade-2 
and Padel, no definite trend was noticed. At all growth stages, the range of available iron was deficient as per the nutrient norms given by Raghupathi and Bhargava (1999). Medeiros et al., (2004) also observed increase in iron content of leaves at flowering stage over to pre-flowering stage and they have also noticed decrease in iron content at fruit ripening stage at Brazil.

The increase in content due to foliar application of micronutrients prior to flowering and up to egg stage and the iron content found to have decreased at fruit ripening stage because of its absorption by fruit for the development of fruit and its colour.

\section{Total manganese (Mn)}

The periodic determination of total manganese of mango orchard of different locations is presented in table 3. At Warwade1 and Padel, the total manganese gradually increased from pre-flowering to flowering stage and then decreased up harvest.

While, at Warwade-2 and Rameshwar it increased up to egg stage and at harvest, it found to have decreased. As per the ratings given by Raghupathi and Bhargava (1999), the total manganese comes under high category at all growth stages. The increase in manganese content of leaves from preflowering stage to flowering stage at mango orchards of Brazil is studied by Medeiros et al., (2004).

The increase in manganese content due to foliar application of micronutrients prior to flowering and found to have decreased up to fruit ripening stage due to absorption by fruit for the growth and development.

Table.1 Schedule of manure and fertilizer application and foliar spray at different locations

\begin{tabular}{|c|c|c|c|c|c|}
\hline \multirow{2}{*}{$\begin{array}{l}\text { Sl. } \\
\text { No. }\end{array}$} & \multirow{2}{*}{ Particulars } & \multicolumn{4}{|c|}{ Locations } \\
\hline & & Warwade-1 & Warwade-2 & Rameshwar & Padel \\
\hline 1 & Manures & $\begin{array}{l}\text { Ankur Plus } \\
(0.5: 0.5: 0.5 \mathrm{~N}: \mathrm{P}: \mathrm{K}) \\
@ 15 \mathrm{~kg} \text { tree } \\
\text { the } \mathrm{II}^{\text {nd }} \text { week of } \\
\text { June }\end{array}$ & $\begin{array}{l}\text { Green Gold } \\
(0.8: 0.4: 0.4 \mathrm{~N}: \mathrm{P}: \mathrm{K}) \\
@ 20 \mathrm{~kg} \text { tree }{ }^{-1} \text { in the } \\
\text { II }^{\text {nd }} \text { week of June }\end{array}$ & $\begin{array}{l}5 \mathrm{~kg} \text { tree }^{-1} \\
\text { sugarcane } \\
\text { pressmud in the } \\
\text { IIII }^{\mathrm{rd}} \text { week of June }\end{array}$ & $\begin{array}{l}\text { Soil application of } \\
50 \mathrm{~kg} \text { tree }^{-1} \mathrm{FYM} \\
\text { in the } \text { III }^{\text {rd }} \text { week of } \\
\text { June. }\end{array}$ \\
\hline 2 & Fertilizers & $\begin{array}{l}\mathrm{FeSO}_{4} \text { and } \mathrm{MnSO}_{4} \\
@ 10 \mathrm{~g} \text { tree }{ }^{-1} \text { each } \\
\text { prior to flowering. }\end{array}$ & $\begin{array}{l}\mathrm{FeSO}_{4} \text { and } \mathrm{MnSO}_{4} \\
@ 10 \mathrm{~g} \text { tree }{ }^{-1} \text { each } \\
\text { prior to flowering. }\end{array}$ & $\begin{array}{l}\text { 18:18:10 (N: P: K) } \\
\text { @ } 5 \mathrm{~kg} \text { tree }{ }^{-1} \text { in } \\
\text { III }^{\text {rd }} \text { week of June. }\end{array}$ & $\begin{array}{l}\text { 10:26:26 (N: P: K) } \\
\text { @ } 5 \mathrm{~kg} \text { tree }{ }^{-1} \text { in } \\
\text { III }^{\mathrm{rd}} \text { week of June. }\end{array}$ \\
\hline 3 & Foliar spray & 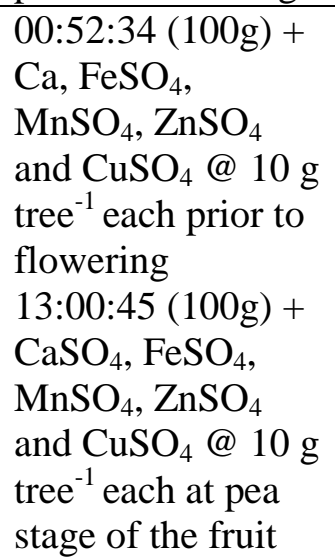 & $\begin{array}{l}\text { 00:52:34 }(100 \mathrm{~g})+ \\
\mathrm{Ca}, \mathrm{FeSO}_{4}, \mathrm{MnSO}_{4} \text {, } \\
\mathrm{ZnSO} \mathrm{Znd}_{4} \text { and } \mathrm{CuSO}_{4} \\
\text { @ } 10 \mathrm{~g} \text { tree }{ }^{-1} \text { each } \\
\text { prior to flowering } \\
\text { 13:00:45 }(100 \mathrm{~g})+ \\
\mathrm{CaSO}_{4}, \mathrm{FeSO}_{4}, \\
\mathrm{MnSO}_{4}, \mathrm{ZnSO}_{4} \text { and } \\
\mathrm{CuSO}_{4} @ 10 \mathrm{~g}^{-1} \mathrm{tre}^{-1} \\
\text { each at marble stage } \\
\text { of the fruit }\end{array}$ & $\begin{array}{l}11.4 \mathrm{~g} \mathrm{~N}, 1.75 \mathrm{~g} \mathrm{P}, \\
10 \mathrm{~g} \mathrm{~K}, 13.5 \mathrm{~g} \mathrm{~S}, \\
5.25 \mathrm{~g} \mathrm{Zn}, 6.25 \mathrm{~g} \\
\mathrm{Cu}, 5 \mathrm{~g} \mathrm{~B}, 3.25 \mathrm{~g} \\
\mathrm{Mo},(\mathrm{Amrashakti}) \\
+10 \mathrm{~g} \mathrm{KNO}_{3} \text { and } \\
10 \mathrm{~g} \mathrm{Ca}^{-1} \text { tree }^{-1} \text { at } \\
\text { flowering and } \\
\text { marble stage of the } \\
\text { fruit }\end{array}$ & $\begin{array}{l}11.4 \mathrm{~g} \mathrm{~N}, 1.75 \mathrm{~g} \mathrm{P}, \\
10 \mathrm{~g} \mathrm{~K}_{13.5 \mathrm{~g} \mathrm{~S},} \\
5.25 \mathrm{~g} \mathrm{Zn}, 6.25 \mathrm{~g} \\
\mathrm{Cu}, 5 \mathrm{~g} \mathrm{~B}, 3.25 \mathrm{~g} \\
\mathrm{Mo}, 10 \mathrm{~g} \mathrm{CaSO}_{4}, \\
10 \mathrm{~g} \mathrm{FeSO}_{4} \text { and } 5 \\
\mathrm{~g} \mathrm{MnSO}_{4} \text { tree }^{-1} \text { at } \\
\text { flowering and } \\
\text { marble stage of } \\
\text { the fruit }\end{array}$ \\
\hline
\end{tabular}


Table.2 Average soil nutrient status at different stages of Alphonso mango orchards from different locations

\begin{tabular}{|c|c|c|c|c|c|c|c|c|c|c|c|c|c|c|c|c|}
\hline \multirow{2}{*}{ Loc. } & \multicolumn{4}{|c|}{ Available Fe $\left(\mu \mathrm{g} \mathrm{g}^{-1}\right)$} & \multicolumn{4}{|c|}{ Available Mn $\left(\mu \mathrm{g} \mathrm{g}^{-1}\right)$} & \multicolumn{4}{|c|}{ Available $\mathrm{Zn}\left(\mu \mathrm{g} \mathrm{g}^{-1}\right)$} & \multicolumn{4}{|c|}{ Available $\mathrm{Cu}\left(\mu \mathrm{g} \mathrm{g}^{-1}\right)$} \\
\hline & $\mathrm{PF}$ & $\mathrm{F}$ & $\mathrm{E}$ & $\mathrm{AH}$ & $\mathrm{PF}$ & $\mathrm{F}$ & $\mathrm{E}$ & $\mathrm{H}$ & $\mathrm{PF}$ & $\mathrm{F}$ & $\mathrm{E}$ & $\mathrm{AH}$ & $\mathrm{PF}$ & $\mathrm{F}$ & $\mathrm{E}$ & $\mathrm{AH}$ \\
\hline $\mathrm{W}-1$ & 41.61 & 42.23 & 42.43 & 38.37 & 109.57 & 78.00 & 136.25 & 33.00 & 1.13 & 0.92 & 0.62 & 0.60 & 5.42 & 4.74 & 4.62 & 3.90 \\
\hline $\mathrm{W}-2$ & 75.91 & 74.13 & 62.02 & 53.89 & 138.86 & 174.75 & 175.29 & 84.02 & 2.86 & 2.70 & 1.07 & 1.64 & 7.65 & 7.53 & 6.99 & 5.77 \\
\hline $\mathrm{R}$ & 29.09 & 34.73 & 34.81 & 37.07 & 78.75 & 45.20 & 79.58 & 68.10 & 1.22 & 1.12 & 0.64 & 1.35 & 5.85 & 5.98 & 5.78 & 5.41 \\
\hline $\mathrm{P}$ & 116.74 & 112.31 & 102.17 & 162.42 & 102.53 & 31.75 & 79.66 & 64.63 & 4.31 & 4.20 & 2.43 & 5.26 & 6.79 & 6.21 & 6.19 & 6.10 \\
\hline
\end{tabular}

Table.3 Average leaf nutrient contents at different stages of Alphonso mango orchards from different locations

\begin{tabular}{|c|c|c|c|c|c|c|c|c|c|c|c|c|c|c|c|c|}
\hline \multirow{2}{*}{ Loc. } & \multicolumn{4}{|c|}{ Total Fe $\left(\mu \mathrm{g} \mathrm{g}^{-1}\right)$} & \multicolumn{4}{|c|}{ Total Mn $\left(\mu \mathrm{g} \mathrm{g}^{-1}\right)$} & \multicolumn{4}{|c|}{ Total Zn $\left(\mu \mathrm{g} \mathrm{g}^{-1}\right)$} & \multicolumn{4}{|c|}{ Total $\mathrm{Cu}\left(\mu \mathrm{g} \mathrm{g}^{-1}\right)$} \\
\hline & $\mathrm{PF}$ & $F$ & $E$ & $\mathrm{AH}$ & $\mathrm{PF}$ & $\mathrm{F}$ & $E$ & $\mathrm{H}$ & $\mathrm{PF}$ & $\mathrm{F}$ & $E$ & $\mathrm{AH}$ & $\mathrm{PF}$ & $\mathrm{F}$ & $E$ & $\mathrm{AH}$ \\
\hline $\mathrm{W}-1$ & 246.47 & 297.35 & 392.64 & 235.83 & 452.58 & 480.98 & 464.37 & 437.37 & 23.93 & 17.99 & 24.38 & 15.83 & 16.65 & 19.07 & 28.72 & 37.50 \\
\hline $\mathrm{W}-2$ & 202.57 & 306.34 & 294.69 & 312.40 & 392.51 & 433.46 & 450.69 & 429.43 & 24.04 & 30.41 & 21.43 & 15.19 & 20.31 & 24.01 & 9.64 & 26.83 \\
\hline $\mathrm{R}$ & 210.13 & 268.35 & 311.97 & 237.63 & 471.82 & 536.15 & 560.86 & 484.05 & 23.10 & 24.04 & 22.19 & 14.60 & 20.98 & 19.80 & 11.00 & 95.00 \\
\hline $\mathrm{P}$ & 286.84 & 284.33 & 485.22 & 295.85 & 315.34 & 391.17 & 379.23 & 328.04 & 39.10 & 30.71 & 26.33 & 19.05 & 27.95 & 23.67 & 16.07 & 91.65 \\
\hline
\end{tabular}

Table.4 Yield of mango orchard of different locations

\begin{tabular}{|l|c|c|c|c|}
\hline \multirow{2}{*}{ Contents } & \multicolumn{4}{|c|}{ Locations } \\
\cline { 2 - 5 } & Warwade-1 & Warwade-2 & Rameshwar & Padel \\
\hline Average Yield $\left(\mathrm{kg} \mathrm{tree}^{-1}\right)$ & 49.73 & 155.20 & 25.82 & 57.60 \\
\hline
\end{tabular}

Table.5 Correlation between available soil nutrients and yield of mango orchard of Different locations at different growth stages

\begin{tabular}{|c|c|c|c|c|c|c|c|c|}
\hline \multirow{2}{*}{ Parameters } & \multicolumn{3}{|c|}{ W-1 \& W-2 (Ratnagiri tahasil) } & \multicolumn{3}{c|}{ R \& P (Devgad tahasil) } \\
\cline { 2 - 9 } & $\mathrm{PF}$ & $\mathrm{FF}$ & $\mathrm{E}$ & $\mathrm{AH}$ & $\mathrm{PF}$ & $\mathrm{FF}$ & $\mathrm{E}$ & $\mathrm{H}$ \\
\hline $\mathrm{Fe}$ & $0.58^{*}$ & $0.67^{*}$ & 0.51 & $0.60^{*}$ & $0.68^{*}$ & 0.70 & $0.62^{*}$ & $0.76^{*}$ \\
\hline $\mathrm{Mn}$ & 0.18 & $0.55^{*}$ & 0.18 & $0.58^{*}$ & 0.28 & -0.35 & -0.18 & -0.08 \\
\hline $\mathrm{Zn}$ & $0.61^{*}$ & $0.68^{*}$ & 0.27 & $0.59^{*}$ & 0.45 & $0.63^{*}$ & $0.49^{*}$ & $0.64^{*}$ \\
\hline $\mathrm{Cu}$ & $0.59^{*}$ & $0.62^{*}$ & $0.58^{*}$ & $0.55^{*}$ & 0.04 & 0.10 & -0.19 & $0.51^{*}$ \\
\hline
\end{tabular}


Table.6 Correlation between leaf nutrients and yield of mango orchard of Different locations at different growth stages

\begin{tabular}{|c|c|c|c|c|c|c|c|c|}
\hline \multirow{2}{*}{ Parameters } & \multicolumn{3}{|c|}{ W-1 \& W-2 (Ratnagiri tahasil) } & \multicolumn{3}{c|}{ R \& P (Devgad tahasil) } \\
\cline { 2 - 9 } & $\mathrm{PF}$ & $\mathrm{FF}$ & $\mathrm{E}$ & $\mathrm{AH}$ & $\mathrm{PF}$ & $\mathrm{FF}$ & $\mathrm{E}$ & $\mathrm{H}$ \\
\hline $\mathrm{Fe}$ & -0.04 & -0.02 & -0.40 & 0.30 & 0.59 & -0.02 & $0.48^{*}$ & $0.55^{*}$ \\
\hline $\mathrm{Mn}$ & -0.40 & -0.28 & -0.005 & -0.08 & -0.72 & -0.28 & -0.70 & -0.75 \\
\hline $\mathrm{Zn}$ & -0.01 & $0.50^{*}$ & -0.28 & -0.25 & 0.22 & $0.50^{*}$ & $0.40^{*}$ & 0.45 \\
\hline $\mathrm{Cu}$ & $0.41^{*}$ & $0.66^{*}$ & -0.59 & -0.20 & $0.46^{*}$ & $0.66^{*}$ & $0.55^{*}$ & -0.06 \\
\hline
\end{tabular}

\section{Total zinc (Zn)}

At Warwade-1, the total zinc content in leaf decreased from pre-flowering stage up to flowering. At egg stage, it increased and again decreased at harvest stage. In case of Warwade-2 and Rameshwar it increased at flowering and further declining trend was observed up to harvest. While, at Padel decreasing trend was noticed from preflowering stage up to harvest of the fruits (Table 3). As per the nutrient norms given by Raghupathi and Bhargava (1999), the total zinc was excess at pre-flowering and egg stage, while it was optimum at flowering and harvest of the fruits. At Brazil, the increase or decrease in total zinc content in leaves of 'Tommy Atkins' mangoes at phenological stages was noticed by Medeiros et al., (2004). The increase in total zinc might de due to foliar application on leaves and decrease may be due to its translocation it from leaves to fruits as per requirement of fruit for its growth and development.

\section{Total copper $(\mathbf{C u})$}

The continuously increasing trend was observed from pre-flowering stage up to at harvest stage in case of total copper at Warwade-1 location. At Warwade-2, it decreased from pre-flowering stage up to flowering while, at egg stage, it increased and again decreased at harvest stage.
In case of Rameshwar and Padel, decreasing trend was observed up to egg stage and at harvest stage, it increased gradually. As per the nutrient norms of Raghupathi and Bhargava (1999), the total copper content was sufficient at all stages except harvesting stage.

At harvest, the total Mn content was excess. Similar values of copper up to egg stage were noticed by Sukthumrong et al., (2000) and values of copper at maturity and the increasing trend of copper are in conformity with Medeiros et al., (2004). The increase in nutrient content reflected due to application of foliar products containing nutrients and decrease in content at egg stage might be due to its translocation from leaves to fruit.

As seen from table 4 the average yield of Warwade-1, Warwade-2, Rameshwar and Padel locations were 49.73, 155.20, 25.82 and $57.60 \mathrm{~kg}$ tree $^{-1}$. The average yield of Warwade-2 location was higher, while the average yield of Rameshwar was low amongst all locations.

\section{Correlation}

In the present investigation, among the selected four mango orchards, Warwade-1 and Warwade-2 are in close vicinity in Ratnagiri tahasil while, Rameshwar and Padel are in close vicinity in Devgad tahasil. So for correlation purpose, correlation of nutrients was found out within Ratnagiri (including 
both Warwade-1 and Warwade-2) and Devgad tahasil (including both Rameshwar and Padel). The data showed that available micronutrient content in the soil and total micronutrients in the leaf of Alphonso mango orchards were found to be positively and negatively correlated, which suggested the existence of dynamic equilibrium between them.

\section{Correlation between available soil nutrients and yield of mango orchards}

A perusal of the data presented in table 5 revealed that available iron, available zinc and available copper exhibited positive and significant correlation with yield at preflowering stage; available iron, available manganese, available zinc and available copper at flowering stage; available copper at egg stage and available iron, available manganese, available copper and available zinc at harvest at Warwade-1 and Warwade-2 (Ratnagiri) locations.

Whereas positive and significant relationship was found between yield and available iron at pre-flowering stage; available zinc at flowering stage; available iron and available zinc at egg stage and available iron, available zinc and available copper at harvest of the fruits at Rameshwar and Padel (Devgad) locations. The positive and significant correlation indicates available soil micronutrients (Fe, $\mathrm{Mn}, \mathrm{Zn}$ and $\mathrm{Cu}$ ) proved beneficial in increasing fruit yield.

\section{Correlation between available leaf nutrients and yield of mango orchards}

The data presented in table 6 when studied revealed that total copper exhibited positive and significant correlation with yield at preflowering stage and total zinc and copper at flowering stage at Warwade- 1 and Warwade2 (Ratnagiri) locations. Whereas positive and significant relationship was found between yield and total copper at pre-flowering stage; total zinc and copper at flowering stage; total iron, zinc and copper at egg stage and total iron at harvest of the fruits at Rameshwar and Padel (Devgad) locations. The total Fe, Zn and $\mathrm{Cu}$ contents in the leaves proved that they were beneficial in increasing the yield of mango.

In conclusion, the study revealed that there is positive significant correlation between available nutrients in soil and corresponding nutrient in plant which indicates that soil application of nutrients is beneficial. The location wise yield levels showed that the mango yield is dependent on fertilizer management of the orchard.

\section{References}

Anonymous, (2015). Indian Horticulture Database, published by National Horticulture Board.

Chinchmalatpure, A.R., Brij, L., Challa, O. and Sehgal, J. (2000). Available micronutrient status of soils on different parent materials and landforms in a micro-watershed of Wunna catchment near Nagpur (Maharashtra). Agropedology, 10, 53-58.

Diwan, P. M. (1982). Micronutrient status of the soils from bench terraced area of the Central Farm, Wakawali. M.Sc. (Agri.) Thesis submitted to Konkan KrishiVidyapeeth, Dapoli, Dist. Ratnagiri, Maharashtra (Unpublished).

Katyal, J.S., Sharma, B.D. and Mehta, S.K. (1982). 14 ${ }^{\text {th }}$ Annual report of ICAR's All India Co-ordinated scheme of micronutrients in soil and plant for the year 1980-81, pp 63.

Lindsay, W.L. (1991) inorganic equilibria affecting micro-nutrients in soil. "Micro- nutrients Agriculture", $2^{\text {nd }}$ edition (J. J. Martvedt, F. R. Cox, L.M. 
Shurman and R. M. Welch Eds.), Soil Sci. Soc. America, Medison, W. L. pp 89-112.

Lindsay, W.L. and Norvell, W.A. (1978). Development of DTPA soil test for $\mathrm{Zn}, \mathrm{Fe}, \mathrm{Mn}$ and $\mathrm{Cu}$. Soil Science of America Journal 42:421-428.

Mclaren, C.A. and Crawford, M.S. (1950). Soil Sci. Soc. America J. 37, 309.

Mehta, B.V. and Patil, N.K. (1967). Forms of Manganese and their distribution in soil profiles of Kaira district in Gujarat. J. Indian Soc. Soil Sci. 15, 41-47.

Medeiros, A.A. (2004). Mineral composition of leaves and fruits of irrigated mango trees in riogrande do Norte State, Brazil. International Soc. for Horti. Sci. 403408.stages of flowering and fruit growth. Indian J. Hort., 35, 302-14.

Pathmanabhan, G., Vanagamudi, M., Chandrasekaran, C.N., Sathyamoorthi, K., Raja Babu, C. and Boopathi, D. (2008). A Handbook on Mineral Nutrition and Diagnostic Techniques for Nutritional Disorders of Crops published by AGROBIOS, Jodhpur.

Patil, K.D. and M.B. Meisheri (2004). Minerological studies and DTPAExtractable $\mathrm{Zn}, \mathrm{Cu}, \mathrm{Mn}$ and $\mathrm{Fe}$ in representative soils of Konkan region. J. Maharashtra Agril. Univ., 29 (1): 4-8.

Patil, K.D., Salvi, B.R. and Chavan, A.S. (2010). Effect of Foliar Application of Nutrients to Alphonso Mango in Lateritic Soils of Konkan. J. Indian Soc. Coastal agric. Res. 28 (1): 40-43.
Pawar, S.S. (2012). Micronutrient Status of Soil from Mango Orchards of Sindhudurg District and their Relationship with Soil Properties. M.Sc. (Agri.) Thesis submitted to BalasahebSawant Konkan KrishiVidyapeeth, Dapoli, Dist. Ratnagiri, Maharashtra (Unpublished). Raghupathi, H.B. and Bhargava, B.S. (1999). Preliminary diagnostic soil fertility norms for Alphonso mango (Mangifera indica L.). Journal of Indian Society of Soil Sci. 45 (3): 534-536.

Reddy, Y.T.N., Kurian, R.M., Sujatha, M.T. and Shrinivas, M. (2003). Indian Institute of Horti. Res. 60 (2): 121-126.

Salvi, V. G. (1988). Physico-chemical properties and available micronutrient status of the rice soils from Agricultural Research Station, Palghar (Thane) M.Sc. (Agri.) Thesis submitted to Konkan KrishiVidyapeeth, Dapoli, Dist. Ratnagiri, Maharashtra (Unpublished).

Tandon, H.L.S., (1993). Methods of analysis of soils, plants, water and fertilizers. FAO and consultation Org., New Delhi.

Tisdale, L. Samuel, Werner L. Nelson, James D. Beaton and John L. Havlin (1993). Soil fertility and fertilizers published by Prentice, Hall of India Private Limited, New Delhi. p. 316, 321, 325, 335 and 336.

Yawalkar, K.S., Agarwal J.P. and Bokde S. (2011). Manures and Fertilizers published by Agri-Horticultural Publishing House, Nagpur.

\section{How to cite this article:}

Puranik, U.Y., Manoj Kumar Dev, S.D. Zodge and Prabhudesai, S.S. 2017. Periodical Changes in Soil and Leaf Micronutrients and their Relation to Yield from Alphonso Mango Orchards of Ratnagiri and Devgad, Maharashtra, India. Int.J.Curr.Microbiol.App.Sci. 6(7): 1144-1151. doi: https://doi.org/10.20546/ijcmas.2017.607.139 